\title{
AKTIVITAS FISIK MEMENGARUHI FUNGSI KOGNITIF LANSIA
}

\author{
Mersiliya Sauliyusta $^{1 *}$, Etty Rekawati $^{2}$ \\ 1. Program Studi Sarjana Fakultas Ilmu Keperawatan Universitas Indonesia, Kampus UI, Depok 16424, Indonesia \\ 2. Fakultas Ilmu Keperawatan Universitas Indonesia, Kampus UI, Depok 16424, Indonesia \\ *E-mail: mersi.liya@gmail.com
}

\begin{abstract}
Abstrak
Penurunan fungsi kognitif merupakan keadaan normal yang dialami oleh lansia. Keadaan ini dapat dikurangi atau dihambat dengan cara meningkatkan aktivitas fisik. Tujuan penelitian ini adalah untuk mengetahui hubungan antara tingkat aktivitas fisik dengan fungsi kognitif lansia. Desain penelitian ini adalah cross sectional dengan metode cluster sampling dengan jumlah sampel sebanyak 104 responden lansia. Sampel penelitian ini rata-rata didominasi lansia perempuan yang berusia 60-74 tahun, tidak lulus SD/tidak sekolah, masih berstatus menikah, dan memiliki penyakit kronis. Hasil penelitian menunjukkan ada hubungan antara tingkat aktivitas fisik dengan fungsi kognitif lansia $(\mathrm{p}=0,000 ; \mathrm{a}=0,05)$. Perawat diharapkan dapat mencegah penurunan fungsi kognitif dengan cara meningkatkan aktivitas fisik lansia berupa latihan fisik. Selain itu, penelitian selanjutnya diharapkan dapat melakukan studi mengenai intensitas, durasi, frekuensi, dan jenis latihan fisik yang paling baik untuk meningkatkan fungsi kognitif pada lansia.
\end{abstract}

Kata kunci: aktivitas fisik, fungsi kognitif, lansia

\begin{abstract}
Physical Activity Affecting Elderly Cognitive Function. Declining the cognitive function is a normal situation in which elderly usually experienced. This condition might be decreased or inhibited by increasing the physical activities. The purpose of this research was to identify the relation between physical activity with the cognitive function of the elderly. Research design used cross sectional approach with cluster sampling method on 104 elderly people. This research sample dominated by female elderly age 60-74 years old, not graduated from junior high school/not registered in school, married status, and having chronic diseases. The result showed that there is relationship between level of physical activity and the cognitive function of elderly $(p=0,000 ; a=0,05)$. Nurses are expected to prevent declining the cognitive function through increasing physical activity in the form of physical exercise. Moreover, the next research is expected to continue the study about the intensity, duration, frequency, and other kinds of physical exercise which are good to increase the cognitive function for the elderly.
\end{abstract}

Keywords: cognitive function, elderly, physical activity

\section{Pendahuluan}

Jumlah lansia di Indonesia tiap tahunnya mengalami peningkatan. Menurut Badan Pusat Statistik (2013) proyeksi jumlah lanjut usia ( $\geq 60$ tahun) di Indonesia pada tahun 2014 diperkirakan mencapai 207.930.000 jiwa, dan pada tahun 2035 diperkiran mencapai 481.987.0000 juta jiwa. Peningkatan jumlah lansia di Indonesia secara signifikan membuat Indonesia masuk dalam 5 besar negara yang memiliki populasi lansia terbanyak di Dunia (World Health Organization, 2014).
Peningkatan jumlah lansia ini juga berdampak pada peningkatan usia harapan hidupnya di Indonesia. Berdasarkan laporan Perserikatan Bangsa Bangsa 2011, pada tahun 2000-2005 usia harapan hidup mencapai 66,4 tahun (dengan persentase lansia tahun 2000 sebesar 7,74\%). Angka ini akan meningkat pada tahun 2045-2050 yang diperkirakan usia harapan hidup menjadi 77,6 tahun (dengan persentase populasi lansia pada tahun 2045 sebesar 28,68\%). Badan Pusat Statistik (BPS) juga mengatakan terjadi peningkatan usia harapan hidup, dari 64,5 tahun (dengan persentase po- 
pulasi lansia sebesar $7,18 \%$ ) pada tahun 2000 menjadi 69,43 pada tahun 2010 (dengan persentase populasi lansia sebesar $7,56 \%$ ), dan pada tahun 2011 menjadi 69,65 tahun (dengan persentase populasi lansia sebesar 7,58\%) (Pusat Data dan Informasi Kementerian Kesehatan RI, 2013).

Meningkatnya proporsi lanjut usia, menimbulkan beberapa masalah kesehatan pada lansia. Berdasarkan data dari Pusat Data dan Informasi Kementrian Kesehatan RI (2013), masalah kesehatan terbesar lansia adalah penyakit degeneratif. Diperkirakan pada tahun 2050 sekitar $75 \%$ lansia penderita penyakit degeneratif tidak dapat beraktivitas. Penyakit degeneratif pada lansia salah satunya adalah penurunan fungsi kognitif. Fungsi kognitif merupakan proses mental dalam memperoleh pengetahuan atau kemampuan serta kecerdasan, yang meliputi cara berpikir, daya ingat, pengertian, perencanaan, dan pelaksanaan (Santoso \& Ismail, 2009).

Pada dasarnya, fungsi kognitif akan mengalami penurunan secara normal seiring dengan penambahan usia. Selain itu, ada faktor risiko yang dapat memengaruhi penurunan fungsi kognitif yaitu keturunan dari keluarga, tingkat pendidikan, cedera otak, racun, tidak melakukan aktivitas fisik, dan penyakit kronik seperti parkinson, jantung, stroke serta diabetes (The U.S Departement of Health and Human Services, 2011). Sebenarnya, penurunan fungsi kognitif dapat dihambat dengan melakukan tindakan preventif. Salah satu tindakan preventif yang dapat dilakukan lansia yaitu dengan memperbanyak aktivitas fisik (Blondell, Hammersley-Mather, \& Veerman, 2014).

Aktivitas fisik diduga dapat menstimulasi pertumbuhan saraf yang kemungkinan dapat menghambat penurunan fungsi kognitif pada lansia (Muzamil, Afriwardi \& Martini, 2014). Menurut Kirk-Sanchez \& McGough (2013) saat melakukan aktivitas fisik, otak akan distimulasi sehingga dapat meningkatkan protein di otak yang disebut Brain Derived Neutrophic
Factor (BDNF). Protein BDNF ini berperan penting menjaga sel saraf tetap bugar dan sehat. Jika kadar BDNF rendah maka akan menyebabkan penyakit kepikunan.

Namun, sebagian besar lansia malah mengurangi aktivitas fisiknya karena mereka merasa aktivitas fisik seperti olahraga tidak cocok dengan gaya hidup mereka, meskipun ada diantara mereka sadar akan manfaatnya (Lee, Arthur, \& Avis, 2008). Selain itu, lansia mengatakan bahwa dirinya sudah mengalami penurunan kesehatan, sehingga sudah tidak bisa melakukan aktivitas fisik lagi (Baert, Gorus, Mets, Geerts, \& Bautmans, 2011). Berdasarkan laporan dari Physical Activity Council Report (2014) menyatakan bahwa penurunan terbesar aktivitas fisik datang dari dewasa tua berusia 55 tahun sampai seterusnya.

Penelitian sebelumnya yang dilakukan oleh Putri (2013) melaporkan bahwa aktivitas fisik lansia di Kelurahan Mekarwangi Kecamatan Tanah Sareal Kota Bogor tergolong sedang. Hasil dari penelitian tersebut hanya merupakan gambaran tingkat aktivitas fisik yang dilakukan di sana. Namun, belum dikaitkan dengan fungsi kognitif lansia. Maka dari itu, perlu dilakukan penelitian lebih lanjut mengenai hubungan antara tingkat aktivitas fisik dengan fungsi kognitif lansia lansia di Kelurahan Mekarwangi Kecamatan Tanah Sareal Kota Bogor.

\section{Metode}

Penelitian ini merupakan penelitian jenis kuantitatif bersifat deskriptif korelatif. Peneliti menggunakan pendekatan cross sectional dan akan mempelajari hubungan antara faktor risiko (variabel independen) yaitu tingkat aktivitas fisik dengan faktor efek (variabel dependen) yaitu fungsi kognitif lansia diambil secara bersamaan pada satu waktu. Setiap responden hanya diukur satu kali dan pengukuran untuk variabel responden hanya diukur pada saat penyebaran kuesioner (Notoatmodjo, 2010). 
Sampel penelitian adalah 104 lansia di 14 RW di Kelurahan Mekarwangi, Kecamatan Tanah Sareal. Teknik pengambilan sampel yang digunakan peneliti yaitu cluster sampling. Pada teknik ini, peneliti tidak mendaftar semua anggota atau unit yang ada berada dalam suatu populasi, melainkan cukup mendaftar banyaknya kelompok yang ada di dalam populasi itu kemudian mengambil beberapa sampel berdasarkan kelompok-kelompok tersebut (Notoatmodjo, 2010).

Langkah selanjutnya adalah menentukan jumlah responden dari tiap RW yang dihitung menggunakan rumus proporsi sebagai unit yang mewakili sampel yang diteliti. Kriteria inklusi sampel penelitian yaitu lansia yang berusia $\geq 60$ tahun, tinggal di Kelurahan Mekarwangi, tidak memiliki gangguan psikiatrik dan dapat berkomunikasi menggunakan bahasa Indonesia.

Pengambilan data dilakukan dengan menggunakan kuesioner sebagai instrumen penelitian yang dibagikan kepada lansia. Kuesioner yang digunakan terdiri dari 3 bagian. Kuesioner 1 berisi tentang data demografi, bagian 2 berisi pertanyaan tentang aktivitas fisik dan bagian ke 3 mengenai fungsi kognitif lansia. Instrumen aktivitas fisik menggunakan kuesioner A Physical Activity for the Elderly (Vorrips, 1991) dan Instrumen fungsi kognitif menggunakan Mini Mental State Examination (Folstein, Folstein, \& McHugh, 1975 dalam Wallace, 1999).

Data yang didapat kemudian diolah dan diproses menggunakan sistem program komputer. Data dianalisis secara univariat dan bivariat dengan uji proporsi pada setiap variabel penelitian, meliputi tingkat aktivitas fisik dan fungsi kognitif lansia. Peneliti menggunakan uji chi square dengan kemaknaan $\mathrm{p}<0,05$ untuk mengetahui hubungan antara tingkat aktivitas fisik lansia dengan fungsi kognitif lansia.

\section{Hasil}

Fungsi Kognitif. Berdasarkan Tabel 1 dapat dilihat bahwa jumlah lansia yang memiliki fungsi kognitif normal, selisihnya tidak jauh dengan lansia yang mengalami penurunan fungsi kognitif. Namun, tetap nilai fungsi kognitif normal lebih tinggi yaitu sebesar $54,8 \%$ yang diukur menggunakan instrumen penelitian MMSE.

Tabel 1. Fungsi Kognitif Responden

\begin{tabular}{lcc}
\hline Kategori Fungsi Kognitif & Jumlah & $\begin{array}{c}\text { Persentase } \\
(\boldsymbol{\%})\end{array}$ \\
\hline Fungsi Kognitif Normal & 57 & 54,8 \\
Penurunan Fungsi Kognitif & 47 & 45,2 \\
\hline
\end{tabular}

Tingkat Aktivitas Fisik. Berdasarkan Tabel 2 dapat dilihat bahwa jumlah lansia yang memiliki tingkat aktivitas fisik tinggi dan rendah berimbang yaitu sebanyak $50 \%$. Jadi, tingkat aktivitas fisik di Kelurahan Mekarwangi Kecamatan Tanah Sareal Kota Bogor hasilnya tidak ada yang mendominasi.

Tabel 2. Tingkat Aktivitas Fisik Responden

\begin{tabular}{lcc}
\hline Kategori Aktivitas Fisik & Jumlah & $\begin{array}{c}\text { Persentase } \\
(\%)\end{array}$ \\
\hline Tinggi & 52 & 50 \\
Rendah & 52 & 50 \\
\hline
\end{tabular}

Hubungan Tingkat Aktivitas Fisik dengan Fungsi Kognitif. Berdasarkan tabel 3 dapat dilihat bahwa terdapat sebanyak $40(76,9 \%)$ responden dengan tingkat aktivitas fisik yang tinggi memiliki fungsi kognitif yang normal. Hasil uji statistik diperoleh nilai $\mathrm{p}=0,000$ maka dapat disimpulkan ada perbedaan proporsi antara tingkat aktivitas fisik dengan fungsi kognitif pada lansia (ada hubungan antara tingkat aktivitas fisik dengan fungsi kognitif). 
Tabel 3. Hubungan Tingkat Aktivitas Fisik dengan Fungsi Kognitif Lansia

\begin{tabular}{|c|c|c|c|c|c|}
\hline \multirow{3}{*}{$\begin{array}{c}\text { Variabel } \\
\text { Tingkat } \\
\text { Aktivitas } \\
\text { Fisik }\end{array}$} & \multicolumn{4}{|c|}{ Fungsi Kognitif Lansia } & \multirow{3}{*}{$\mathbf{p}$} \\
\hline & \multicolumn{2}{|c|}{ Normal } & \multicolumn{2}{|c|}{ Penurunan } & \\
\hline & $\mathbf{n}$ & $\%$ & $\mathbf{n}$ & $\%$ & \\
\hline Tinggi & 40 & 76,9 & 12 & 23,1 & 0,00 \\
\hline Rendah & 17 & 32,7 & 35 & 67,3 & $\begin{array}{c}0,00 \\
0\end{array}$ \\
\hline Total & 57 & 54,8 & 47 & 45,2 & \\
\hline
\end{tabular}

\section{Pembahasan}

Hasil analisis hubungan antara tingkat aktivitas fisik dengan fungsi kognitif lansia diperoleh bahwa responden dengan tingkat aktivitas fisik yang tinggi memiliki fungsi kognitif yang normal. Hasil uji statistik diperoleh nilai $\mathrm{p}=0,000$ maka dapat disimpulkan ada hubungan antara tingkat aktivitas fisik dengan fungsi kognitif. Penelitian lain yang mendukung penelitian ini dilakukan Clouston, et al., (2013) yang menyatakan bahwa ada hubungan antara tingkat aktivitas fisik dengan fungsi kognitif pada lansia. Selain itu, Auyeung, et al., (2008) menyatakan bahwa seseorang yang kurang melakukan aktivitas fisik dan kekuatan otot biasanya akan mengalami kerusakan fungsi kognitif.

Menurut Muzamil, Afriwardi, dan Martini (2014), tingkat aktivitas fisik yang tinggi dan rutin mempunyai hubungan dengan tingginya skor fungsi kognitif. Namun, lansia yang memiliki tingkat aktivitas rendah atau sedang berhubungan dengan penurunan fungsi kognitif, khususnya memori dan fungsi bahasa (Makizako, et al., 2014). Studi yang dilakukan oleh Busse, et al., (2009) menunjukkan bahwa aktivitas fisik dapat meningkatkan fungsi eksekutif, perhatian, kecepatan berpikir, kerja memori serta memori jangka panjang/pendek.

Menurut Jones dan Rose (2005) dengan melakukan program aktivitas fisik jangka pendek seperti latihan fisik dapat membawa perbaikan yang berarti dalam kinerja fungsi kognitif lansia. Selain itu, dengan melakukan akti- vitas fisik secara rutin dan berkala termasuk berjalan kaki akan membuat fungsi kognitif menjadi lebih baik. Hal ini karena aktivitas fisik dapat mempertahankan aliran darah yang optimal dan mengantarkan nutrisi ke otak. Apabila lansia tidak melakukan aktivitas fisik secara rutin maka aliran darah ke otak menurun, dan akan menyebabkan otak kekurangan oksigen. (Marhamah, 2008; Weuve, et al., 2004).

Aktivitas fisik juga diduga menstimulasi pertumbuhan saraf yang kemungkinan dapat menghambat penurunan fungsi kognitif pada lansia (Muzamil, Afriwardi, \& Martini, 2014). Menurut Kirk-Sanchez dan McGough (2013) saat melakukan aktivitas fisik, otak akan distimulasi sehingga dapat meningkatkan protein di otak yang disebut Brain Derived Neutrophic Factor (BDNF). Protein BDNF ini berperan penting menjaga sel saraf tetap bugar dan sehat. Namun, apabila kadar BDNF rendah maka akan menyebabkan penyakit kepikunan (Antunes, et al., 2006).

Menurut National Institute on Aging (2009), aktivitas fisik merupakan kegiatan memindahkan/menggerakkan badan seperti berkebun, berjalan, dan menaiki tangga. Namun, aktivitas fisik berbeda dengan latihan fisik. Latihan fisik merupakan bagian dari aktivitas fisik yang lebih terstruktur atau terjadwal seperti aerobik dan tai chi. Latihan fisik sebenarnya lebih memengaruhi fungsi kognitif pada lansia. Menurut Bherer, Erickson, dan Ambrose (2013), latihan fisik seperti aerobik akan meningkatkan kemampuan kognitif lansia khususnya bagian kontrol eksekutif dan meningkatkan volume hippocampus. Hippocampus merupakan sentral otak yang sangat penting dalam menyimpan memori (Sankanparan, 2010).

Aktivitas fisik memiliki empat dimensi utama yaitu jenis, frekuensi, durasi, dan intensitas fisik (Gibney, 2009). Menurut Kerr, et al., (2013) sebaiknya aktivitas fisik pada lansia dilakukan selama tiga kali seminggu dengan 
durasi 30 menit. Hal ini akan berdampak baik pada peningkatkan fungsi kognitif sebesar $20 \%$ pada proses kontrol eksekutif seperti perencanaan, penjadwalan, memori, gangguan kontrol, dan kordinasi tugas kerja.

Intensitas aktivitas fisik merupakan seberapa keras suatu aktivitas dilakukan. Biasanya diklasifikasikan menjadi intensitas ringan, sedang, dan berat (Landefeld, et al., 2004). Namun, pada penelitian ini aktivitas fisik dibagi menjadi dua bagian yaitu rendah dan tinggi berdasarkan klasifikasi dari kuesioner aktivitas fisiknya. Hal ini juga dikarenakan data hasil penelitian tidak normal sehingga klasifikasinya menggunakan nilai median sebesar 5,84. Hasil dari penelitian ini menemukan bahwa lansia yang memiliki aktivitas fisik rendah dan tinggi sebesar $50 \%$. Itu artinya tidak ada yang mendominasi antara aktivitas fisik rendah dan aktivitas fisik tinggi.

Namun demikian, penurunan fungsi kognitif memang tidak bisa dihindari karena bisa saja terjadi akibat perubahan fisiologis struktur otak yang terjadi secara normal seiring dengan pertambahan usia (Miller, 2012). Hasil dari penelitian ini mendapatkan data bahwa jumlah lansia yang memiliki fungsi kognitif normal sedikit lebih banyak yaitu sebesar 54,8\% karena lansia di Kelurahan Mekarwangi didominasi oleh lansia muda. Penelitian lain yang mendukung hasil penelitian ini adalah yang dilakukan oleh Wreksoatmodjo (2014), yang menjelaskan bahwa lansia yang memiliki fungsi kognitif normal juga lebih banyak yaitu sebesar 62,2\%. Klasifikasi fungsi kognitif juga dibagi menjadi dua bagian, yaitu fungsi kognitif normal dan penurunan fungsi kognitif. klasifikasi menggunakan nilai median yaitu 24. Hasil penelitian ini tidak terdistribusi dengan normal karena data yang didapat tidak bervariasi.

Lain halnya dengan penelitian yang dilakukan oleh Brown, et al., (2012), yang menyatakan bahwa aktivitas fisik tidak berhubungan dengan fungsi kognitif. Hasil dari penelitian ini terjadi karena aktivitas fisik yang diukur terlepas dari intensitas sehingga tidak memengaruhi fungsi kognitif sehari-hari (Haley, 2013). Studi lain yang dilakukan oleh Kerr, et al., (2013) mengatakan jika semua tingkat intensitas aktivitas fisik digabungkan menjadi satu ukuran MET jam/hari, tidak ada hubungan yang terlihat antara aktivitas fisik dengan fungsi kognitif lansia. Selain itu, aktivitas rumah tangga yang dilakukan oleh lansia hanya sedikit memengaruhi fungsi kognitif.

Bherer, Erickson, dan Ambrose (2013) juga menyatakan masih belum mengerti dampak aktivitas fisik terhadap tingkat penurunan fungsi kognitif. Salah satu isu utama adalah apakah aktivitas fisik didefinisikan secara luas atau latihan terstruktur yang mengarah ke manfaat yang sama dalam mencegah penurunan kognitif. Maka dari itu, masih belum diketahui dimensi aktivitas fisik mana yang paling memengaruhi fungsi kognitif pada lansia. Penelitian selanjutnya diperlukan untuk memahami intensitas, durasi, dan jenis latihan yang lebih baik untuk meningkatkan fungsi kognitif pada lansia. Oleh karena itu, penurunan fungsi kognitif salah satunya dapat dicegah dengan melakukan aktivitas fisik khususnya latihan fisik. Aktivitas fisik yang baik dilakukan selama $\geq 150 \mathrm{menit} / \mathrm{minggu}$ dapat berdampak pada peningkatan fungsi kognitif (Makizako, et al., 2014). Beberapa studi menyarankan lansia untuk mengadopsi aktivitas fisik dan olahraga sebagai bagian dari gaya hidup mereka agar mengurangi dampak negatif pada tubuh dan pikiran (Bherer, Erickson, \& Ambrose, 2013).

\section{Kesimpulan}

Hasil penelitian ini menunjukkan jumlah lansia dengan fungsi kognitif yang normal lebih banyak dibanding dengan lansia yang sudah mengalami penurunan fungsi kognitif. Tingkat aktivitas fisik lansia proporsinya sama yaitu $50 \%$. Jadi, lansia yang memiliki tingkat aktivitas fisik tinggi dan rendah berimbang dan tidak saling mendominasi satu sama lain. 
Namun demikian analisis bivariat menunjukkan bahwa ada hubungan bermakna antara tingkat aktivitas fisik dengan fungsi kognitif lansia.

Hasil dari penelitian ini dapat dijadikan masukan bagi para tenaga kesehatan, khususnya perawat komunitas untuk mengoptimalkan peran perawat dalam memberikan layanan keperawatan terkait upaya pencegahan penurunan fungsi kognitif dengan cara meningkatkan aktivitas fisik lansia berupa latihan fisik. Halhal yang bisa dilakukan oleh perawat komunitas dengan cara mengetahui jenis-jenis aktivitas fisik yang bisa dilakukan oleh lansia sesuai dengan kemampuannya untuk meminimalisir kejadian cedera atau hal-hal yang tidak diinginkan terjadi pada lansia (ER, TN, PN).

\section{Referensi}

Antunes, H.K., Santos, R.F., Cassilhas, R., Santos, R.V., Bueno, O.F., \& Mello, M,T. (2006). Reviewing on physical exercise and the cognitive function. Rev Bras Med Esporte, 12 (9), 97-103. doi: http://dx.doi.org/10.1590/S1 517-86922006000200011

Auyeung, T.W., Kwok, T., Lee, J., Leung, P.C., Leung, J., \& Woo, J. (2008). Functional decline in cognitive impairment-the relationship between physical and cognitive function. Neuroepidemiology, 31, 167-173. doi: 10.1159 /000154929.

Badan Pusat Statistik. (2013). Proyeksi penduduk indonesia 2010-2035. Jakarta: Badan Pusat Statistik Indonesia.

Baert, V., Gorus, E., Mets, T., Geerts, C., \& Bautmans, I. (2011). Motivators and barriers for physical activity in older old: a systematic review. Ageing Research, 10. 464-476. doi: 10.1016/j.arr.2011.04.001

Bherer, L., Erickson, K.I., \& Ambrose, T.L. (2013). A review of the effects of physical activity and exercise on cognitive and brain functions in older adults. Hindawi Publishing Corporation. 2013 (1), 1-6. doi: 10.1155

\section{/2013/657508.}

Blondell, S.J., Hammersley-Mather, R., \& Veerman, J.L. (2014). Does physical activity prevent cognitive decline and dementia?: A systematic review and meta-analysis of longitudinal studies. BMC Public Health, 14(1), 1-12. doi: 10.1186/1471-2458-14-510.

Brown, B., Peiffer, J., Sohrabi, H., Mondal., A., \& Gupta, V.B. (2012). Intense physical activity is associated with cognitive performance in the elderly. Ecu Publications, 2012 (2), e191. doi: 10.1038/tp.2012.118.

Busse, A.L., Gil, G., Santarem, J.M., \& Filho, W.J. (2009). Phyical activity and cognition in the elderly a review. Dementia Neuropsychologia, 3 (3), 204-208.

Clouston, S.A., Brewster, P., Kuh, D., Richards, M, Cooper, R.,...., Hofer, S.M. (2013) The dynamic relationship between physical function and cognition in longitudinal aging cohorts. Epidemiologic Reviews, 35 (1), 33-50. doi: 10.1093/epirev/mxs004.

Gibney, et al. (2009). Public health nutrition (Alih Bahasa: Andry Hartono). Jakarta: Penerbit Buku Kedokteran EGC.

Haley, C. (2013). Exploring the relationship between physical activity and everyday cognitive function in older adults: Within and between person variability. South Florida: University of South Florida.

Jones, C.J \& Rose, D.J. (2005). Physical activity instruction of older adults. United States of America: Human Kinetics.

Kerr, J., Marshall, S.J., Patterson, R.E., Marinac, C.R., Natrajan, L.,..., Crist, K. (2013). Objectively measured physical activity is related to cognitive function in older adults. National Institutes of Health, 61 (11), 1-10. doi: 10.1111/jgs.12524.

Kirk-Sanchez, N.J., \& McGough, E.L. (2013). Physical exercise and cognitive performance in the elderly: Current Perspectives. Dovepress, $9,51-62$. 
Landefeld, S.C, , et al. (2004). Current geriatric diagnosis\&treatment. Singapore: The Mc Graw-Hills Company.

Lee, L.L., Arthur, A., \& Avis, M. (2008). Using self-efficacy theory to develop interventions that help older oepole overcome psychological barriers to physical activity: a discussion paper. International Journal of Nursing Studies, 45, 1690-1699. doi: http://dx.doi.org/ 10.1016/j.ijnurstu.2008.02.012

Makizako, H., Shimada, H., Doi, T., Park, H., Tsutsumimoto, K.,..., Suzuki, T. (2014). Moderate-intensity physical activity, cognition and apoe genotype in older adults with mild cognitive impairment. Science Medical Central, 1 (1), 1-5.

Marhamah. (2008). Konsumsi gizi dan aktivitas fisik usia lanjut di kota depok kaitannya dengan stauts kesehatan dan kemampuan kognitif (Skripsi, Universitas Terbuka). Universitas Terbuka, Jakarta.

Miller, C.A. (2012). Nursing for wellness in older adults (6th Ed.). Philadelphia: Lippincott Williams \& Wilkins.

Muzamil, M.S, Afriwadi, \& Martini, R.D. (2014). Hubungan antara aktivitas fisik dengan fungsi kognitif pada usila di kelurahan jati kecamatan padang timur. Jurnal Fakultas Kedokteran Universitas Andalas, 3 (2), 202-205.

National Institute on Aging. (2009). Exercise \& physical activity. Georgia: National Institute of Health.

Notoatmodjo, S. (2010). Metodologi penelitian kesehatan. Jakarta: Rineka Cipta.

Physical Activity Council. (2014). 2014 participation report. USA: Sports Marketing Survey USA.
Pusat Data dan Informasi Kementrian Kesehatan RI. (2013). Gambaran kesehatan lanjut usia di indonesia. Jakarta: Kementrian Kesehatan RI.

Putri, H.E. (2013). Gambaran tingkat aktivitas fisik lansia di kelurahan mekarwangi kecamatan tanah sareal kota bogor (Skripsi, Universitas Indonesia). Universitas Indonesia, Jakarta.

Sankanparan, H. (2010). Otak tengah memang dahsyat. Jakarta: Transmedia Pustaka.

Santoso, H., \& Ismail, A. (2009). Memahami krisis lanjut usia. Jakarta: Gunung Mulia.

The U.S Departement of Health and Human Services. (2011). Physical activity and health older adults. Washington DC: Pennsylvania Avenue.

Voorrips, L.E., Ravelli, A.C., Dongelmans, P.C., Deurenberberg, P., \& Staveren, W.A. (1990). A physical activity questionnaire for the elderly. Official Journal of the American College of Sports Medicine, 23 (8), 974-979.

Wallace, M. (1999). The mini mental state examination. Hartford Institute for Geriatric Nursing, (3). Diperoleh dari https://www.mo unt sinai .on.ca/ care/psych/on-call-resources/ on-call-resources/mmse.pdf

Weuve, J., Kang, J.H., Manson, J.E., Breteler, M.M., Ware, J.H., \& Grodstein, F. (2004). Physical activity, including walking, and cognitive function in older women. JAMA, 292 (12), 1454-1459.

World Health Organization. (2014). Regional strategy for healthy ageing. India: WHO Publications.

Wreksoatmodjo, B.R. (2014). Beberapa kondisi fisik dan penyakit yang merupakan faktor risiko gangguan fungsi kognitif. $C D K-212,41$ (1), 25-32. 